\title{
Mutagenic Improvement of Xylanase Production from Xylanolytic Bacteria and its Phylogenetic Analysis
}

\author{
CHUSNUL HANIM ${ }^{1 *}$, LIES MIRA YUSIATI ${ }^{1}$, MUHAMMAD NUR CAHYANTO $^{2}$, \\ AND ALI WIBOWO ${ }^{1}$
}

\author{
${ }^{1}$ Faculty of Animal Science, Universitas Gadjah Mada, Jalan Fauna 3, Yogyakarta 55281, Indonesia; \\ ${ }^{2}$ Faculty of Agricultural Technology, Universitas Gadjah Mada, Jalan Sosio Yustisia, Bulaksumur, \\ Yogyakarta 55281, Indonesia
}

\begin{abstract}
This study was conducted to obtain xylanolytic mutants that have higher xylanase activity than their wildtype counterparts. A mutant with the best xylanolytic activity was selected and identified based on its 16S rRNA sequence. Its optimum growth condition was also characterized and its phylogenetic relations to other xylanolytic bacteria were analyzed. Wild type xylanolytic alkalophlic bacteria were grown in medium containing xylan as a substrate. Mutation was performed using ethidium bromide (EtBr) or ethyl methanesulfonate (EMS) at concentrations 50,100, and $150 \mathrm{mg} \mathrm{mL}^{-1}$ and times of exposure 30,60, 90, and $120 \mathrm{~min}$ for each treatment. Twenty two mutants were obtained from EtBr and 24 mutants from EMS mutageneses. The mutants were analyzed for their capability to secrete xylanase into xylan medium containing xylose or glucose or glycerol. Growth optimizations of the mutant were done in media with $\mathrm{pH}$ range 6-11 and temperature range 30 to $60{ }^{\circ} \mathrm{C}$. Mutant number 19, which was obtained by treatment using $50 \mathrm{mg} \mathrm{mL}^{-1}$ EMS for $120 \mathrm{~min}$, had the highest xylanase activity $\left(15.057 \mathrm{U} \mathrm{g}^{-1}\right)$. This activity was obtained at optimum growth conditions: $\mathrm{pH} 9.5$ and temperature $55^{\circ} \mathrm{C}$. Chromosomal DNA of this mutant was extracted and amplified by PCR using 16S rRNA gene specific primers. The amplified fragments were sequenced by dideoxynucleotide chain terminator method. The phylogenetic analysis based on 16S rRNA gene sequence showed that mutant 19 was closed to an anaerobic xylanase producing bacteria.
\end{abstract}

Key words: ethidium bromide, ethyl methanesulfonate, mutagenesis, xylanolytic bacteria

Penelitian ini bertujuan untuk memperoleh mutan bakteri xilanolitik yang mempunyai aktivitas xilanase lebih tinggi dari aslinya, dan mengetahui kondisi optimum pertumbuhan mutan, serta mengidentifikasinya menggunakan 16S rRNA untuk menjelaskan kekerabatan dengan bakteri penghasil xilanase lain. Bakteri penghasil enzim xilanolitik alkalofilik dari hasil penelitian terdahulu ditumbuhkan dalam medium xilan. Mutasi dilakukan menggunakan EtBr atau EMS pada konsentrasi 50, 100, dan $150 \mathrm{mg} \mathrm{mL}^{-1}$, dengan lama pemaparan 30,60, 90, dan 120 menit setiap perlakuan mutagen. Mutan yang diperoleh ditumbuhkan dalam medium xilan yang mengandung xilosa atau glukosa atau gliserol, kemudian dianalisis aktivitas xilanasenya. Optimalisasi pertumbuhan mutan dilakukan pada $\mathrm{pH}$ medium 6 sampai 11 dan suhu 30 sampai $60{ }^{\circ} \mathrm{C}$ di dalam medium yang mengandung xilan sebagai substrat. Dari hasil penelitian diperoleh 22 mutant hasil mutasi menggunakan EtBr dan 24 mutan dari mutasi dengan EMS. Mutan dengan kode 19 yang merupakan hasil mutasi menggunakan $50 \mathrm{mg} \mathrm{mL}^{-1}$ EMS selama 120 menit menghasilkan aktivitas xilanase tertinggi yaitu $15,057 \mathrm{U} \mathrm{g}^{-1}$. Mutan tersebut tumbuh pada $\mathrm{pH}$ optimum 9,5 dan suhu optimum $55^{\circ} \mathrm{C}$ yang menghasilkan aktivitas xilanase tertinggi. DNA kromosom mutan diekstraksi dan diamplifikasi menggunakan PCR, kemudian dilakukan sekuensing gen 16S rRNA menggunakan metode dideoxynucleotide chain terminator. Berdasarkan analisis pohon filogenetik 16S rRNA diketahui bahwa mutan kode 19 termasuk dalam kerabat bakteri anaerob penghasil xilanase.

Kata kunci: bakteri xilanolitik,etidium bromida, etil metansulfonat, mutagenesis

$\beta$-1,4-linked xylopyranose is the principal component of plant cell wall hemicellulose. The heteropolymer xylan represents the second most abundant hemicellulosic polysaccharide and is composed primarily of xylose, arabinose, and glucuronic acid (Dodd et al. 2009). Hemicellulolytic microorganisms play a significant role in nature by recycling hemicellulose, one of the main components

*Corresponding author; Phone/Fax: +62-274-889477, Email:c.hanim@ugm.ac.id of plant polysaccharides. Microbes use enzymes to hydrolyze xylan into its constituent sugars (Dodd and Cann 2009). A wide variety of microorganisms, including sea and soil bacteria, rumen bacteria, fungi, sea algae, and protozoa, as well as insect and cereals (Sunna and Antranikian 1997), are known to produce xylan-degrading enzymes (Gessesse 1998). Most of the bacteria and fungi secrete extracellular xylanases that hydrolyze hemicellulosic materials to liberate xylose as the end product, allowing the organisms to grow on 
xylan. Many xylanase producers are ruminal microorganisms, possibly due to the high hemicellulose content in the dietary of ruminant animals (Kulkarni et al. 1999). Two principally important enzymes involved in the recycling of hemicellulosic material are endo1,4- $\beta$-xylanases (EC 3.2.1.8), which cleave the xylan backbone, and $\beta$-D-xylosidases (EC 3.2.1.37), which cleave xylose monomers from the nonreducing end of xylo-oligosaccharides (Dodd et al. 2009).

In many cases the synthesis of these enzymes is induced by xylan and repressed by xylose. Mutagenesis can degrade operator gen so that the enzymes are synthesized when repressors are presence (Rajoka et al. 1997). In the past few years further studies on induction and secretion of xylanases had been performed to develop xylanase producers with possible commercial applications. Xylanase production by various bacteria and fungi has been shown to be inducible. However, rare examples of constitutive xylanase expression have also been reported. In general, induction of xylanase production is a complex phenomenon and the level of response to individual inducer varies with the organisms. An inducer for producing maximum xylanase activity in one species may be the inhibitor of the activity in another species. The substrate derivatives and the enzymatic end products may often play a key positive role in the induction of xylanases. They can also act as the end-product inhibitors, possibly at much higher concentrations (Kulkarni et al. 1999).

Ethidium bromide (EtBr) (2,7-diamino-9phenylphenanthridium-1-ethyl bromide) has been used for various biological purposes. EtBr induces petite mutations in yeast. It has been used to eliminate penicillinase plasmids and resistance transfer factors from bacterial cells. It is an inhibitor of nucleic acid biosynthesis and functions as mutagen in bacterial cells. EtBr binds to nucleic acids in vitro and is a commonly used intercalating agent (Bishop and Brown 1973). Intercalating agents induce DNA damages which may cause either killing of cells or induction of mutation and cancer. Most of such damages are subjected to common cellular DNA repair mechanisms, such as excision repair and post-replication repair (Kataoka et al. 1983).

In this study we utilized EtBr and EMS as mutagen to enhance xylanase activity produced by xylanolytic bacteria. We have tried to optimize several growth parameters of the mutants, including medium $\mathrm{pH}$ and temperature. In addition, we studied the phylogenetic relationship between the best mutant and other xylanolytic bacteria.

\section{MATERIAL AND METHODS}

Bacteria and Culture Conditions. The wild-type xylanolytic bacteria were isolated from crabs (Eriocheir sinensis) from previous study as reported by Hanim (2003). Ethidium bromide (EtBr) from Wako and ethyl methane sulfonate (EMS) from Alfa Aesar were used as mutagens.

Xylanolytic bacteria were grown in enrichment medium and recultured in growth medium with xylan as substrate. Incubation was done at $35^{\circ} \mathrm{C}, \mathrm{pH} 11$ for 7 $\mathrm{d}$ in anaerobic condition (Hanim 2003). The enrichment medium contained $1 \mathrm{~g}\left(\mathrm{NH}_{4}\right)_{2} \mathrm{SO}_{4}, 0.5 \mathrm{~g}$ $\mathrm{MgSO}_{4} \cdot 7 \mathrm{H}_{2} \mathrm{O}, 1 \mathrm{~g} \mathrm{~K}_{2} \mathrm{HPO}_{4}, 2 \mathrm{~g} \mathrm{CaCO}_{3}, 10 \mathrm{~g}$ Oat spelt xylan, in $1 \mathrm{~L}$ water, $10 \mathrm{~mL} \mathrm{NaCl} 1 \%$, and $0.1 \%$ resazurin (Skinner 1971). The growth medium contained $1 \mathrm{~g}\left(\mathrm{NH}_{4}\right)_{2} \mathrm{SO}_{4}, 0.1 \mathrm{~g} \mathrm{MgSO}{ }_{4} .7 \mathrm{H}_{2} \mathrm{O}, 7 \mathrm{~g} \mathrm{NaCl}$, $2 \mathrm{gK}_{2} \mathrm{HPO}_{4}, 1 \mathrm{~g}$ yeast extract, in $1 \mathrm{~L}$ water, $0.1 \%$ resazurin, $2 \%$ oat spelt xylan, and $0.5 \%$ cystein $\mathrm{HCl}$ (Skinner 1971).

Mutagenesis and Screening of Mutants. The cultures were grown in defined medium with xylan as substrate, centrifuged $\left(14000 \times \mathrm{g}, 15 \mathrm{~min}, 5^{\circ} \mathrm{C}\right)$, and exposed to different challenging doses of $\mathrm{EtBr}$ (concentration 50, 100, and $150 \mathrm{mg} \mathrm{mL}^{-1}$ ) (Chand et al. 2005), and EMS (concentration 50, 100, and $150 \mathrm{mg}$ $\mathrm{mL}^{-1}$ ) (Rakariyatham et al. 2006), and incubated for 30, 60, 90, 120 min (Chand et al. 2005). Cells surviving these doses were grown in agar medium containing $1 \%$ oat spelt xylan in the presence of $(2 \%$ $\mathrm{w} / \mathrm{w}$ from Oat spelt xylan) glucose, glycerol, or xylose. Two days old colonies were picked and restreaked. Larger colonies were picked for mutant selection. The clear zone that produced on xylan+xylose medium was larger than those in presence of glucose or xylose. The larger clear zones around the colonies indicated the higher production of xylan-degrading enzymes. The isolated colonies were subsequently replica-plated on xylan+xylose agar plate. Each colony was studied for production of xylanase in vivo by measuring the diameter of the clear zone as visualized with Congo red spread on the agar plates (Gupta et al. 2000).

Optimization of Xylanase Production. Optimization of xylanase production of the best mutant was performed at $\mathrm{pH}$ range 6 to 11, and temperature range 30 to $60{ }^{\circ} \mathrm{C}$ on xylan $+x y l o s e$ substrate. The incubation was performed at anaerobic condition for $5 \mathrm{~d}$. The composition of growth medium was described above. Culture medium was centrifuged at $14000 \times \mathrm{g}$ for 15 min at $5{ }^{\circ} \mathrm{C}$. The supernatant was carefully separated 
from the pellet and measured for xylanase activity. We measured the protein concentration during the growth.

Enzyme Assays. Xylanase activity was determined by measuring the increase of reducing sugar concentration formed by enzymatic hydrolysis of soluble oat spelt xylan. Enzyme sample $(0.2 \mathrm{~mL})$ was mixed with $0.2 \mathrm{~mL}$ of $4 \%(\mathrm{w} / \mathrm{v})$ soluble oat spelt xylan and $0.4 \mathrm{~mL} 50 \mathrm{mM}$ sodium acetate buffer $(\mathrm{pH} 6)$. The mixture was then incubated at $50{ }^{\circ} \mathrm{C}$ for $20 \mathrm{~min}$ (Ruiz-Arribas et al. 1995). The reducing sugar generated was quantified by Nelson Somogyi method (Plummer 1978) using D-xylose as standard. One unit of enzyme activity was defined as the amount of enzyme that catalyzed the liberation of $1 \mu \mathrm{mol}$ of reducing sugar per min.

Protein Determination. Protein content was determined by Lowry method as described by Plummer (1978). Five $\mathrm{mL}$ of alkaline copper sulphate reagent was added to $2 \mathrm{~mL}$ extracellular protein sample. The mixture was then left to stand for $10 \mathrm{~min}$ at room temperature, followed by addition of $0.5 \mathrm{~mL}$ Folin-Ciocalteu phenol reagent, standing for $30 \mathrm{~min}$ at room temperature, and measuring the absorbance at $750 \mathrm{~nm}$ using bovine serum albumin as the standard.

DNA Extraction and PCR Conditions. Bacterial DNA was extracted using versatile quick-prep method for genome of Gram-positive bacteria (Pospiech dan Neumann 1995 modified). The DNA extraction was prepared with lysozyme and proteinase $\mathrm{K}$, and then purified using microclean kit.

16S rDNA from mutants were amplified by PCR with the 16S rDNA degenerate primer F8 [5'AGAGTTTGATC(A/C)TGGCTC-3'] and universal reverse primers R1492 [5'-GNTACCTTGTTACGAC TT-3'] (Bera-Maillet et al. 2004). PCR was done using Mega Mix Blue kit. For PCR amplification, 30 cycles were conducted in an automated thermocycler. The following parameters were used; denaturation step for $30 \mathrm{~s}$ ( $2 \mathrm{~min}$ for the first cycle) at $94{ }^{\circ} \mathrm{C}$, annealing step for $2 \mathrm{~min}$ at $52{ }^{\circ} \mathrm{C}$, and extension step for $45 \mathrm{~s}$ at $72{ }^{\circ} \mathrm{C}$.

Phylogenetic Analysis. The purified DNA was sequenced with an automatic sequencer. The $16 \mathrm{~S}$ rRNA nucleotide sequences were aligned using CLUSTAL_X (Thompson et al. 1997). All sequence data retrieved from GenBank database were used for comparative purposes. The alignments were analyzed using PHYLIP program (Felsenstein 1993), followed by analysis of the output file using Neighbor program. Similarity and difference of the nucleotide sequences were analyzed by PHYDIT program (Chun 1999).

\section{RESULTS}

Screening for Xylan-Degrading Activities. The mutation using EtBr and EMS showed different effects on the viability and xylanase activity of xylanolytic bacteria. EtBr inhibited the growth of xylanolytic bacteria at much lower concentrations than EMS. Several bacterial colonies were still viable upon subculturing after $120 \mathrm{~min}$ exposure to the chemicals. There were 22 mutants surviving after exposure to $\mathrm{EtBr}$, while 24 mutants were found in EMS. Fourty six colonies were screened by substrate overlay method for their ability to degrade oat spelt xylan. Twenty six mutants, that is $21 \mathrm{EMS}(87.5 \%)$ and $5 \mathrm{EtBr}$ mutants (23.81\%), showed clearing zones around the colonies, thus indicating production of xylan-degrading enzymes. Twenty six other mutants failed to produce clearing zone. Mutant code 19, which was exposed to $50 \mathrm{mg} \mathrm{mL}^{-1}$ EMS for $120 \mathrm{~min}$, was re-cultured in medium with xylan plus xylose as substrates. The mutant had the highest specific xylanase activity (15.057 $\mathrm{U} \mathrm{g}^{-1}$ ). Previous study showed that xylanase activity of the wild-type was $9.317 \mathrm{U} \mathrm{g}^{-1}$. Therefore, there was an increase $(61.61 \%)$ of xylanase activity of mutant code 19 compared to its wild-type.

Effect of $\mathrm{pH}$ and Temperature on Xylanase Production. Mutant 19's optimum incubation time for optimum xylanase activity and microbial protein concentration was $5 \mathrm{~d}$ (data is not shown). It was shorter than the wild-type's (7 d). The results (Fig 1) clearly demonstrated that medium $\mathrm{pH}$ influence xylanase production of this mutant. Fig 2 showed that temperature affected xylanase production. The optimum temperature was $55^{\circ} \mathrm{C}$, which produced the maximum xylanase activity. However, enzyme activity decreased sharply after incubation at lower or higher than the optimum temperature.

Phylogenetic Analyses. Phylogenetic relationships of mutant 19 to other xylanolytic bacteria available in the GenBank (Xylanibacterium ulmi LMG 21721 [accesion number NR 029089], Xylanibacterium ulmi XIL08 [Ay273185], Ruminobacter amylophilus DSM 43089 [Y15992], Xylanibacter oryzae KB3 [Ab078826], Ruminococcus albus ATCC 27210 [L76598], Ruminococcus flavefaciens ATCC 19208 [L76603], Blautia hansenii DSM 20583 [M59114], S. caprinus strain ACM3969 [Y10868], Streptococcus gallolyticus ACM 3611 [X94337], S. alactolyticus ATCC 43077 [Af201899], S. caballi strain 151 


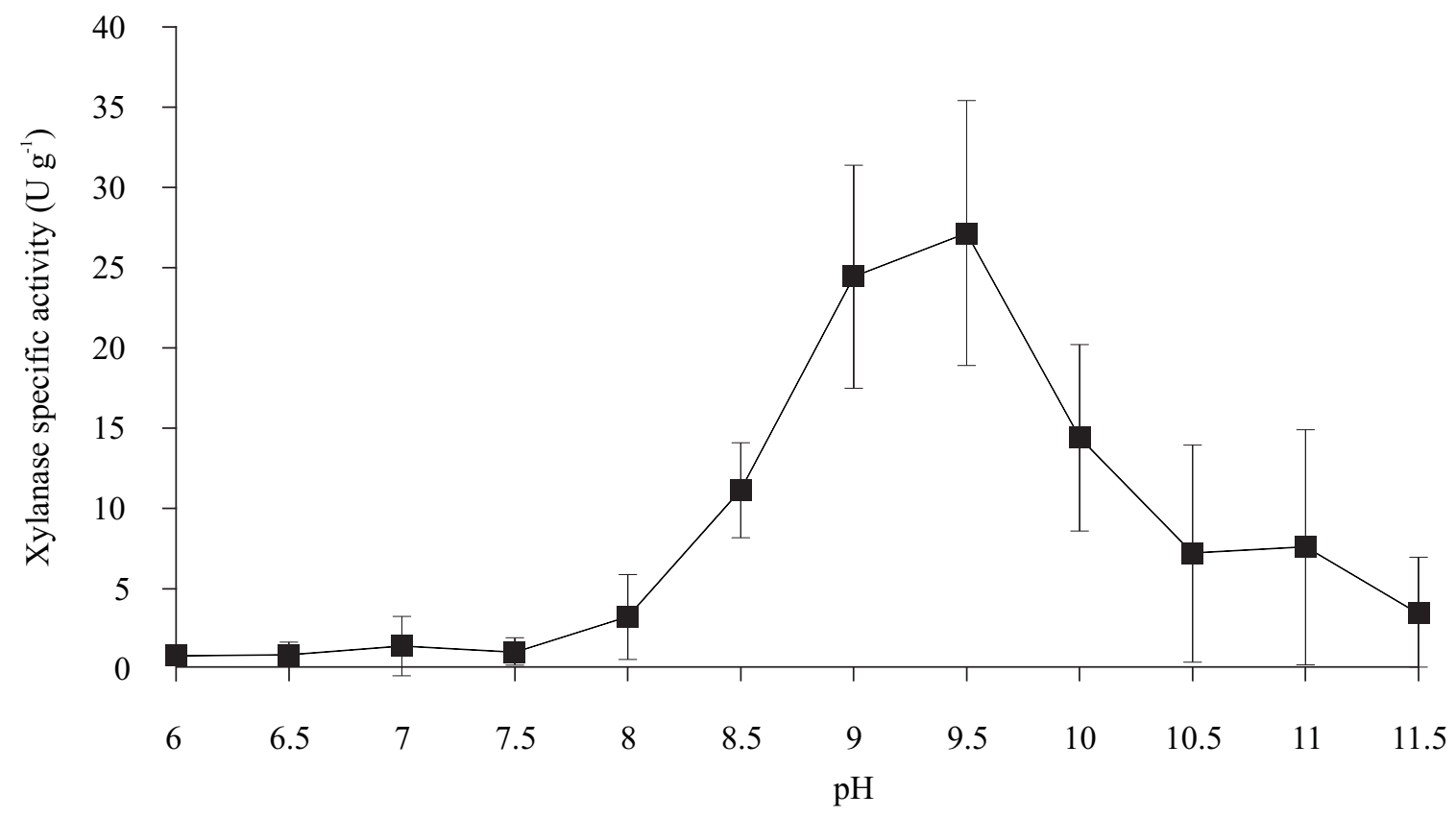

Fig 1 Effect of $\mathrm{pH}$ on the extracellular xylanase activity produced by xylanolytic mutant 19 grown anaerobically on xylan medium containing $2 \%$ xylose, at $35^{\circ} \mathrm{C}$ for $5 \mathrm{~d}$. Xylanase activity was measured in the culture supernatant, and values are means of duplicated measurements. Each point is the mean of standard deviation (SD) (indicated by error bar) from two different experiments.

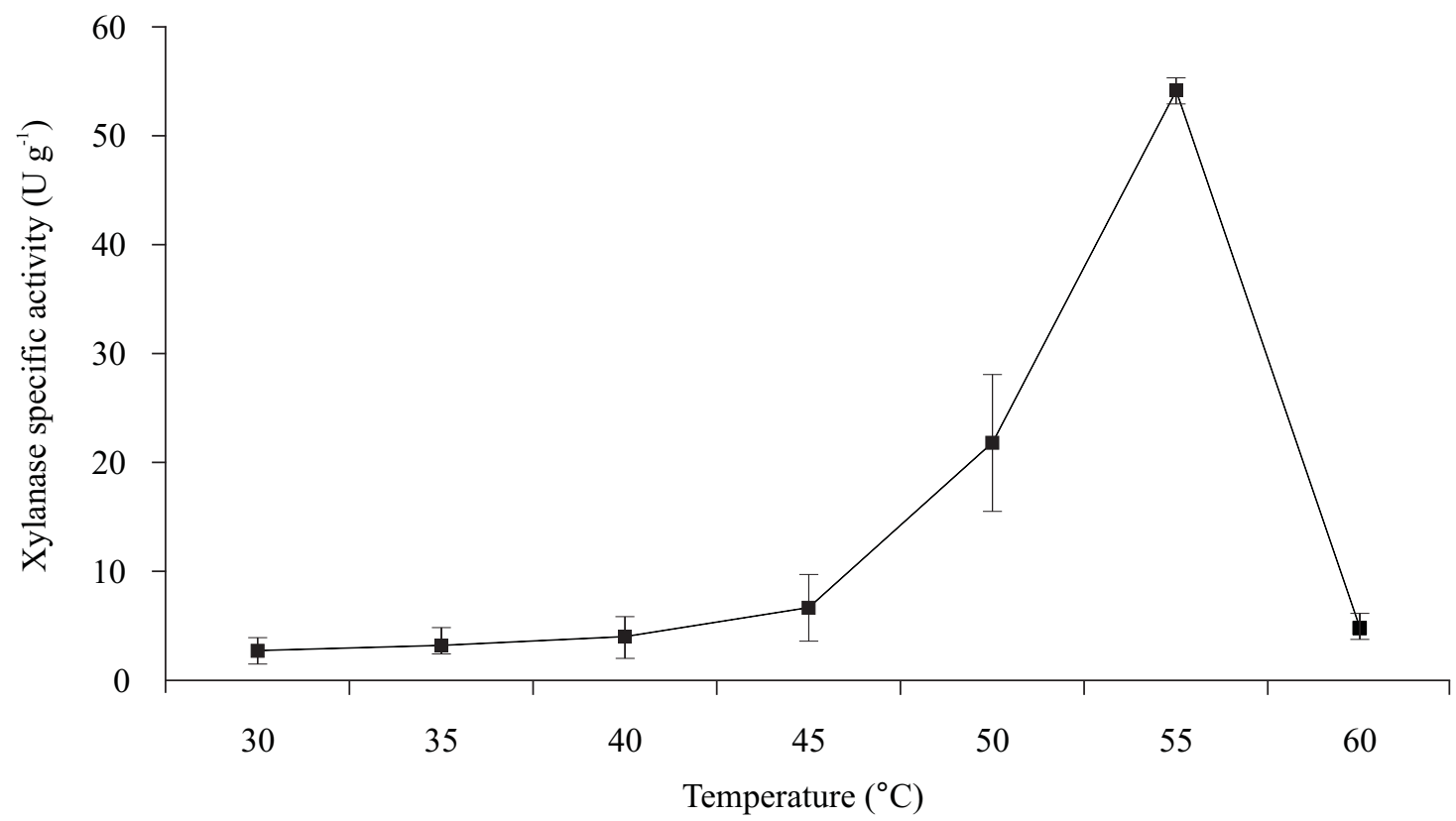

Fig 2 Effect of temperature on the activity of extracellular xylanase of xylanolytic mutant 19 grown on xylan medium containing $2 \%$ xylose at anaerobic condition, $\mathrm{pH} 9.5$ for $5 \mathrm{~d}$. Xylanase activity was measured in the culture supernatant and values are means of duplicated measurements. Bars represent standard deviation (SD) for two different cultures.

[EF364098], S. dysgalactiae subsp. equisimilis strain CIP 105120 [Dq232540], S. ictaluri strain 707-05 [DQ462421], and S. gallinaceus CCUG42692T [AJ307888]), were analyzed. Similarity value and number of nucleotide differences derived from analysis of 16S rRNA sequences between mutant 19 and the other xylanase-producing strains are shown (Table 1). In spite of their overall similarity, the sequence obtained could be used to subdivide the isolates into three groups (Fig 3). The first group included strains of X. ulmi, X. oryzae, Blautia hansenii, and several other strains from different geographic areas. The second and the third group contained Streptococcus. Mutant 19 had more than $82 \%$ similarity to $B$. hansenii DSM 2058, $R$. albus ATCC 27210, and $R$. flavefaciens ATCC 19208 (Table 1). 


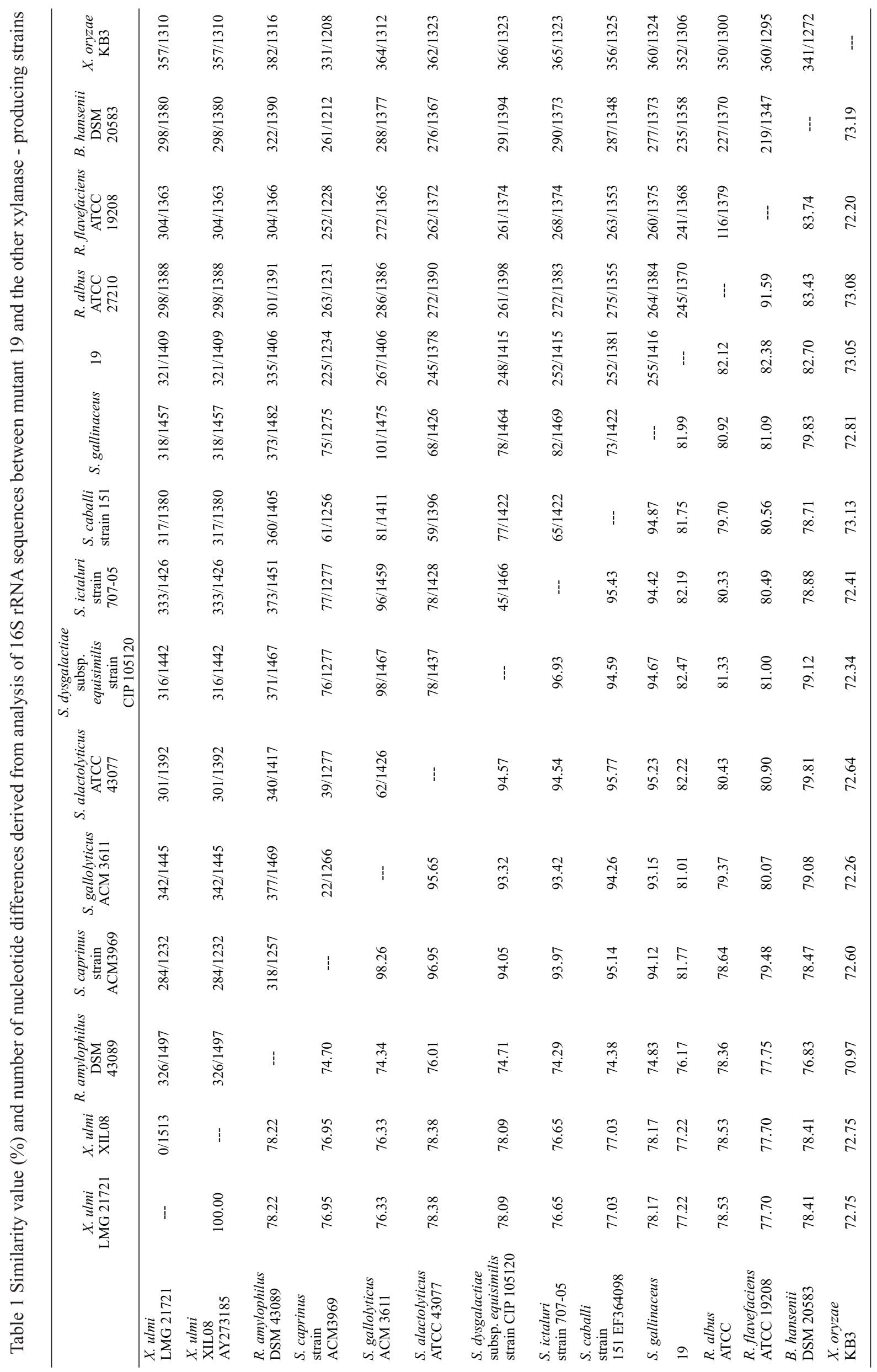




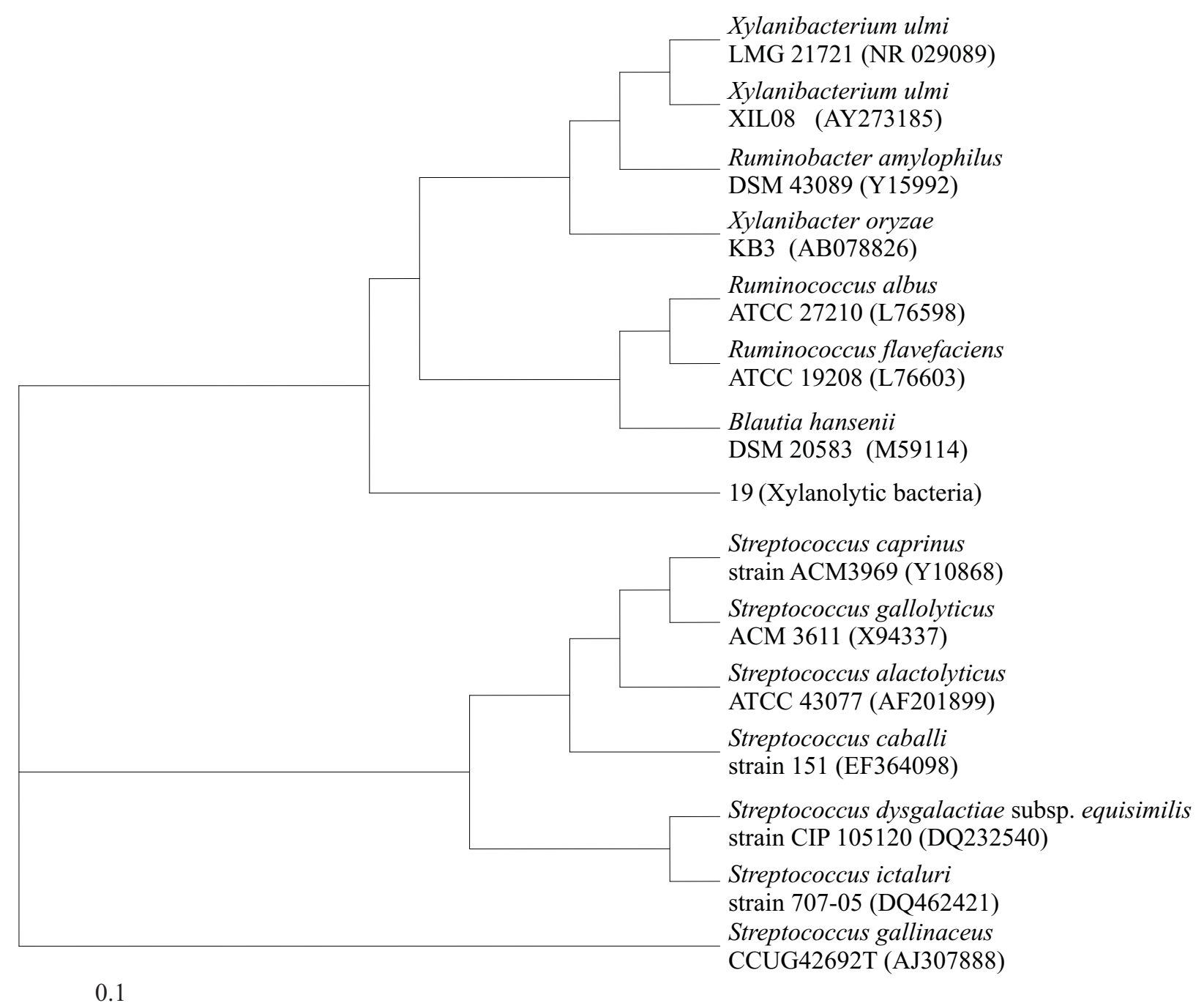

Fig 3 Phylogenetic tree constructed by 16S rRNA gene sequences analysis of mutant 19 and other related xylan-degrading bacteria, with Streptococcus gallinaceus CCUG42692T (AJ307888) as the out-group. Scale bar shows 1 substitution per 10 nucleotides.

\section{DISCUSSION}

$\mathrm{EtBr}$ mutation was more lethal than EMS. EtBr inhibited bacterial growth at much lower concentrations than EMS. Thus, much fewer resistant xylanase producing bacteria were obtained by EtBr mutagenesis. Although EtBr is known to cause cell death, it is not known whether the lethality is due to mutagenicity or to some other toxic effects. Many bacteria are resitant to DNA-intercalating compounds (Lee et al. 1996). Tomchick and Mandel (1964) reported that the growth of Escherichia coli was partially inhibited by $1.2 \times 10^{-4}$ $\mathrm{M} \mathrm{EtBr}$, however, during growth in the presence of ethidium, RNA and protein contents were relatively unaffected. EtBr binds to nucleic acids in vitro and is commonly used as intercalating agent (Bishop and Brown 1973). Alkylating agents induce DNA damages, which may cause either cell death or induction of mutation and cancer (Kataoka et al.1983). The use of different mutagenic agents including ultraviolet (UV), $\mathrm{X}$-rays, gamma radiation, ethyl methane sulfonate (EMS), N-methyl-N-nitro-N-nitrosoguanidine (NTG) and mustards demonstrated improvement for cellulase production (Sangkharak et al. 2012). Lee et al (1985) reported a mutant of strain ATCC 824 was obtained by selection on larch xylan agar medium after exposure of the wild-type strain to $1 \%$ (vol/vol) ethyl methanesulfonate. The xylanase activity of this mutant, XYN 1, was about two fold higher when grown on oat spelt xylan at $\mathrm{pH} 6.0$ than when grown on larch xylan at pH 5.2. In this study, we resulted xylanase activity of mutant code 19 was higher than the wild-type. The maximum xylanase activity was detected at pH $9.5\left(27.09 \mathrm{U} \mathrm{g}^{-1}\right)$, which was lower than the wild-type's optimum $\mathrm{pH}$. The wild-type's optimum $\mathrm{pH}$ and temperature to produce maximum xylanase activity were 11 and $35{ }^{\circ} \mathrm{C}$, respectively (Hanim 2002).

In order to determine the distribution of xylanase 
during growth on xylan at different temperature and $\mathrm{pH}$ value, the xylanase activity was measured. It was observed previously that the production of xylanase by wild-type bacteria was affected by $\mathrm{pH}$ and temperature of medium (Hanim 2003). Hence, it was important to determine whether the production of xylanase of mutant was also influenced by the $\mathrm{pH}$ and temperature of medium, since this could affect bacterial growth in medium containing xylan as a substrate. The xylanolytic mutant showed maximal xylanase activity at alkaline $\mathrm{pH}$ (9.5). This optimum $\mathrm{pH}$ was 1.5 point lower than its wild-type (11). The optimum temperature was $55^{\circ} \mathrm{C}$. Under these optimum conditions the enzyme showed maximum activity after $5 \mathrm{~d}$ incubation. Kulkarni et al. (1999) reported that the optimum temperature for endoxylanase from bacterial and fungal sources varies between 40 and $60^{\circ} \mathrm{C}$. It was also reported by Kulkarni et al. (1999) that D-xylanases from different organisms are usually stable over a wide $\mathrm{pH}$ range (3-10) and show optimum $\mathrm{pH}$ in the range of 4-7, however, certain alkaliphilic Bacilli are known which have $\mathrm{pH}$ optima for growth and enzyme production at 9-10.

The result of phylogenetic analysis showed that the 16S rRNA sequences of mutant 19 had more than $82 \%$ similarity with the sequence of the closest strains $B$. hansenii DSM 2058, $R$. albus ATCC 27210, and $R$. flavefacie ATCC 19208. Based on the similarity, the mutant was included in the first group including xylanase and cellulose-producing anaerobic bacteria, but this similarity was still less than $99 \%$, thus the mutant cannot be classified in the same genera.

\section{ACKNOWLEDGMENTS}

We thank the Laboratory of Nutritional Biochemistry for supporting our research. This work was supported by research grants from the Ministry of Education and Culture of Indonesia.

\section{REFERENCES}

Bera-Maillet C, Ribot Y, Forano E. 2004. Fiber-degrading of different strains of the genus Fibrobacter. Appl Environ Microbiol. 70(4):2172-2179. doi:10.1128/AE M.70.4.2172-2179.2004.

Bishop PE, Brown, L. R. 1973. Ethidium bromide-resistant mutant of Bacillus subtilis. J Bacteriol. 115(3):10771083.

Chand P, Aruna A, Maqsood AM, Rao LV. 2005. Novel mutation method for increased cellulose production. $\mathrm{J}$ App Microbiol. 98(2):318-323. doi:10.1111/j.13652672.2004.02453.x.
Chun J. 1999. Phylogenetic Editor (PHYDIT). Windows Version.

Dodd D, Cann IK. 2009. Enzymatic deconstruction of xylan for biofuel production. Glob Change Biol Bioenergy. 1:2-17.doi:10.1111/j.1757-1707.2009.01004.x.

Dodd D, Kocherginskaya SA, Spies MA, Beery KE, Abbas CA, Mackie RI, Cann IKO. 2009. Biochemical analysis of a $\beta$-D-xylosidase and a bifunctional xylanase-ferulic acid esterase from a xylanolytic gene cluster in Prevotella ruminicola 23. J Bacteriol. 191 (10): 33283338. doi:10.1128/JB.01628-08.

Felsenstein J. 2002. PHYLIP (Phylogeny Inference Package), Department of Genome Sciences. University of Washington, Seattle, USA.

Gessesse A. 1998. Purification and properties of two thermostable alkaline xylanases from an alkaliphilic Bacillus sp. Appl Environ Microbiol. 64(9):3533-3535.

Gupta N, Reddy VS, Maiti S, Ghosh A. 2000. Cloning, expression, and sequence analysis of the gene encoding the alkali-stable, thermostable endoxylanase from alkalophilic, mesophilic Bacillus sp. strain NG-27. Appl Environ Microbiol. 66(6):2631-2635. doi:10.1128/AEM.66.6.2631-2635.2000.

Hanim C. 2002. Characterization and stability analysis of xylanase from xylanolytic bacteria [thesis]. Yogyakarta (ID): Biotechnology Study Program Inter University Centre, Universitas Gadjah Mada..

Hanim C. 2003. Optimalisasi pertumbuhan bakteri xilanolitik alkalofilik dari ketam (Eriocheir sinensis) [Optimalization of growth of xylanolytic alkalophylic bacteria from crabs (Eriocheir sinensis)]. Buletin Peternakan Universitas Gadjah Mada 27(4):168-176.

Kataoka H, Yamamoto Y, Sekiguchi M. 1983. A new gene (alkB) of Escherichia coli that controls sensitivity to methyl methane sulfonate. J Bacteriol. 153(3):13011307.

Kulkarni N, Shendye A, Rao M. 1999. Molecular and biotechnological aspects of xylanases. FEMS Microbiol Rev. 23:411-456. doi:10.1111/j.1574-6976.1999.tb0040 7.x.

Lee LF, Huang YJ, Chen CW. 1996. Two classes of ethidiurn-bromide-resistant mutants of Streptomyces lividans 66. Microbiology 142(4):1041-1047. doi:10.1 099/00221287-142-4-1041.

Lee SF, Forsberg CW, Gibbins LN. 1985. Xylanolytic activity of Clostridium acetobutylicum. Appl Environ Microbiol. 50(4):1068-1076.

Plummer DT. 1978. An introduction to practical biochemistry. $3^{\text {rd }}$ ed. New Delhi: Tata Mc Graw Hill Publ. Co. Ltd. p 156-157.

Pospiecch A, Neumann B. 1995. A versatile quick-prep of genomic DNA from Gram-positive bacteria. Trends Genet. 11(6):217-218. doi:10.1016/S0168-9525(00)89 052-6.

Rajoka MI, Bashir A, Malik KA. 1997. Mutagenesis of Cellulomonas biazotea for enhanced production of xylanases. Bioresour Technol. 62(3):99-108. doi:10.101 6/S0960-8524(97)00116-8. 
Rakariyatham N, Burt-Indr B, Niamsup H, Shank L. 2006. Improvement of myrosinase activity of Aspergillus sp. NR4617 by chemical mutagenesis. J Biotech. 9(4): 379385 on line. doi:10.2225/vol9-issue4-fulltext-13.

Ruiz-Arribas A, Fernandaz-Abalos JM, Sanchez P, Garda AL, Santamaria RI. 1995. Overproduction, purification, and biochemical characterization of a xylanase (Xys 1) from Streptomyces halstedii JM 8. Appl Environ Microbiol. 61(6):2414 - 2419.

Sangkharak K, Vangsirikul P, Janthachat S. 2012. Strain improvement and optimization for enhanced production of cellulase in Cellulomonas sp. TSU-03. African J Microbiol Res. 6(5):1079-1084. doi:10.5897/AJMR11. 1550 .
Skinner FA. 1971. Isolation of soil Clostridia. In: Isolation of anaerobes. The Society for Applied Bacteriology Technical Series No. 5. London: Academic Press.

Sunna A, Antranikian G. 1997. Xylanolitic enzymes from fungi and bacteria. In: Stewart GG, Russell I, editors. Crit Rev Biotech. 17(1):39-67. doi:10.3109/073885597 09146606.

Thompson JD, Gibson TJ,Plewniak F, Jeanmougin F, Higgins DG. 1997. The C LUSTAL_X windows interface: Flexible strategies for multiple sequence alignment aided by quality analysis tools. Nucl Acids Res. 25(24):4876-4882. doi:10.1093/nar/25.24.4876. 